\title{
Biocomposites from Organic Solid Wastes Derived Biochars: A Review
}

\author{
Qingfa Zhang ${ }^{1,2}$, Hongzhen Cai ${ }^{1}$, Weiming Yi ${ }^{1, *}$, Hanwu Lei ${ }^{2}{ }^{2}$, Haolu Liu ${ }^{3}$, Weihong Wang 4 \\ and Roger Ruan ${ }^{5}$ iD \\ 1 School of Agricultural Engineering and Food Science, Shandong Research Center of Engineering \& \\ Technology for Clean Energy, Shandong University of Technology, Zibo 255000, China; \\ qingfa.zhang@wsu.edu (Q.Z.); chzh@sdut.edu.cn (H.C.) \\ 2 Department of Biological Systems Engineering, Washington State University, Richland, WA 99354, USA \\ 3 Nanjing Institute of Agricultural Mechanization, Ministry of Agriculture and Rural Affairs, \\ Nanjing 210014, China; liuhaolu@caas.cn \\ 4 Key Laboratory of Bio-based Material Science and Technology (Ministry of Education), Northeast Forestry \\ University, 26 Hexing Road, Harbin 150040, China; Weihongwang2001@nefu.edu.cn \\ 5 Center for Biorefining and Department of Bioproducts and Biosystems Engineering University of Minnesota, \\ 1390 Eckles Ave., St. Paul, MN 55108, USA; ruanx001@umn.edu \\ * Correspondence: yiweiming@sdut.edu.cn (W.Y.); hlei@wsu.edu (H.L.)
}

Received: 8 July 2020; Accepted: 3 September 2020; Published: 4 September 2020

check for updates

\begin{abstract}
The replacement of natural fiber with biochars to prepare biocomposites has attracted widespread attention recently. Biochar has unique properties, including the porous structure, large specific surface area, high thermal stability, good conductivity, renewable and abundant feedstock source, and environmental friendliness, which provide excellent properties, environmental benefits, and low production costs for biochar-based composites. Biocomposites from organic solid waste-derived biochars show good prospects worldwide in terms of positive social, environmental, and economic impacts. This paper reviews current biochars, elucidates the effects of biochars on the characteristics and performance of biochar composites, and points out the challenges and future development prospects of biochar composites.
\end{abstract}

Keywords: biocomposites; organic solid waste management; biochar; advances; outlook

\section{Introduction}

The acceleration of urbanization, industrialization, and population growth rapidly increases the production of organic solid wastes [1], which can be divided into agricultural wastes, forestry wastes, industrial processing wastes, and municipal wastes in terms of sources [2]. Traditional disposal methods including incineration and landfill have disturbed the balance of nature and proved to be unfeasible due to air and water pollution. To overcome this issue, many sustainable methods are studied and used to manage organic solid wastes, including composting [3], fermentation [4], thermochemical treatment [5], and preparing biocomposites [6]. The use of plastic products has improved human life, but the non-degradation of most plastics increases the environmental burden seriously [7]. Based on this, biocomposites derived from organic solid wastes and plastics have exhibited good properties and made great progress over the past decades [8]. Generally speaking, biocomposites are prepared using dried organic solid wastes as fillers and polymeric materials as matrixes by melting and compounding, and this indicates that pollution generation can be reduced or eliminated in the productive process of biocomposites [9-11]. Moreover, the biocomposites can be recycled and reutilized in the view of the unique performance of plastics, showing great potential [12]. Although the use of biocomposites displays a sustainable method in managing wastes, there are drawbacks that still cannot be ignored, 
and the main issues of current biocomposites are shown in Figure 1. Compared to fillers, the cost of the polymeric matrix materials such as polyethylene, polypropylene, etc. is high. Decreasing the proportion of the matrix in the biocomposite system can lower the cost but results in poor properties, especially in injection molding. Requirements for high performance in some special conditions demonstrate the fact that there is an urgent need to improve biocomposite properties. The proportion of fillers and the interface structure are the main factors affecting the properties of biocomposites which need to be improved and have attracted the widespread attention of many scholars $[13,14]$. Thus, lots of works have been done on improving the interface structure of biocomposites, including filler modification, matrix modification, and adding agents. The main aim of filler modification is to modify the structure and reduce the polarity of fillers, which are currently achieved using heat treatment [15], steam blasting treatment [16], charge-discharge treatment [17], alkali treatment [18], esterification treatment [19], and etherification treatment [20]. These proved to be effective especially for natural plant fiber fillers. In contrast, matrix modifications such as irradiation treatment [21] and oxidation treatment [22] are mainly realized by increasing its surface tension, increasing its surface polarity, and improving its wettability and adhesion. Due to the opposite polarity between the fillers and matrixes, some coupling agents, such as isocyanate, anhydride, and silane, are added as bridges that can effectively link fillers and matrixes. In addition to coupling agents, some other compatibilizers like chlorinated polyethylene [23], methyl methacrylate-butadiene-styrene copolymer [24], and maleic anhydride [25] can decrease the viscosity of the melt and increase the dispersion of fillers in the matrix, thus improving the interfacial compatibility of biocomposites. All the above three modifications are effective in enhancing the interface interactions and improving the properties of biocomposites, but the resulting increase in costs has become another challenge, as shown in Figure 1.

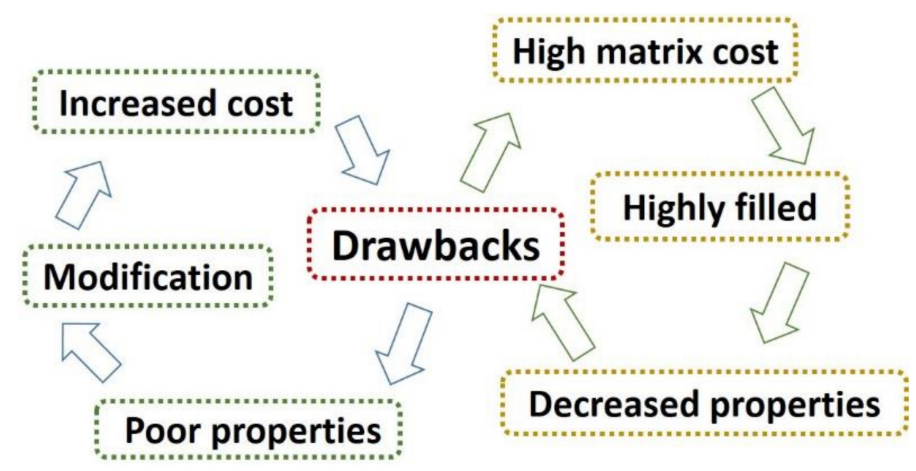

Figure 1. The drawbacks of current biocomposites.

As stated earlier, thermochemical technologies can be considered as one of the effective means to manage organic solid wastes they can create high-value products with no pollution by converting wastes. As the main solid product of thermochemical technologies, biochar is desired for many applications. Recent studies suggest the use of biochars in biocomposites and emphasize minimizing costs and improving properties due to their abundant feedstock and unique structure [26]. Biochar, also named as biocarbon, is usually obtained by gasification or pyrolysis of organic materials under controlled or oxygen-free and high-temperature conditions. All of the organic solid wastes, such as feces, animal bones, agricultural and forestry wastes, can be used as feedstock for producing biochars through a thermochemical process via carbonization or pyrolysis, which can lower the costs for biochar application in biocomposites [27]. The cost of polymer production is much more expensive than biochar due to the complexity of the production processes and the requirements for high-cost raw materials. On the other hand, Bajwa et al. suggested that [28] the coupling agent (e.g., isocyanate, anhydride, etc.) was ineffective for linking polymers and biochars, indicating that the coupling agents in the biochar composite system can be eliminated, which further lowers the costs. After a high-temperature reaction, lots of organic matter is decomposed and volatilized, and most of the functional groups are therefore 
removed, which contributes to the weak polarity of biochars [29]. The weak polarity of the biochars is beneficial for obtaining a better interface combination with hydrophobic polymeric materials. The porous structure of the biochars can also transfer stress in the biochar composite system, and the mechanical properties, therefore, are improved [30]. In addition to the above advantages, good stability, conductivity, and dispersion are also responsible for the feasibility of biochars in biocomposites [31].

The properties of biochar composites can be affected by the type of biochars, type of polymers, loadings of biochars, and preparation temperatures of the biochars, which indicates that biochar properties play a key role in biochar composites [32,33]. Many research articles have explored the mechanical, thermal, and conductivity properties of biochar composites, but the overview of the manufacture and properties of biochar composites is rarely reported. The aim of this paper is to provide details of the main factors of the properties of biochar composites based on biochar properties, while the ultimate goal is to identify the challenges encountered in biochar composites and evaluate the potential of the conversion from organic solid wastes to high-value products.

\section{Biochar}

Biochar production dates back thousands of years, and the earliest biochar was obtained by incomplete combustion under anoxic conditions using stacked and sealed agroforestry residues such as wood, straw, and so on. The growth in application demands accompanied by technological advances means the traditional biochar preparation process cannot meet current needs. Based on the increasing requirements of biochar yield, efficiency, and quality, new biochar preparation technologies have been developed and continuously innovated. The new reactors and their improvements effectively increased the production yield of biochars. Some typical thermochemical conversion reactors are shown in Table 1. The thermochemical conversion technologies are classified as fast pyrolysis and slow carbonization on the basis of the target products. In order to obtain a high yield of biochars, slow carbonization with a slow heating rate is usually used for biochar production.

Table 1. Typical thermochemical conversion reactors.

\begin{tabular}{|c|c|c|c|}
\hline Reactors & Advantages & Disadvantages & References \\
\hline Fluidized bed reactor & $\begin{array}{l}\text { Simple construction, operation and } \\
\text { high efficiency of heat transfer }\end{array}$ & High operation cost & {$[34]$} \\
\hline Vacuum moving bed reactor & Short residence time & Lower transfer rate & [35] \\
\hline Auger reactor & Less complex and low cost & Lower liquid yield & [36] \\
\hline Rotating cone reactor & Using larger particles & Less effective scaling & {$[37]$} \\
\hline Down-tube reactor & $\begin{array}{l}\text { High heat transfer rate and short } \\
\text { residence time }\end{array}$ & Long heat transfer stroke & {$[38]$} \\
\hline Fixed bed reactor & Simple structure & Poor sealing & [39] \\
\hline Microwave reactor & Easy control and energy saving & Lower capacity & {$[40]$} \\
\hline Muffle furnace & $\begin{array}{c}\text { Energy saving and simple } \\
\text { construction }\end{array}$ & Lower capacity & {$[41]$} \\
\hline
\end{tabular}

\subsection{Biochar Properties}

Biochar is a carbon-rich material with a porous structure and low solubility. Biochar is mainly composed of aromatic hydrocarbons and graphite-like structures of carbon, generally containing more than $60 \%$ of the $\mathrm{C}$ element, along with other elements such as $\mathrm{H}, \mathrm{O}, \mathrm{N}$, and $\mathrm{S}$. The aromatic and aliphatic chain structures are important properties of biochars and are the reasons why biochars have strong adsorption and antioxidant capacities [42]. The basic characteristics of biochars can be significantly affected by preparation conditions, including temperature, heating rate, and residence time. Generally speaking, as the preparation temperature increases, the ash content, mineral content, the number of functional groups, the specific surface area, and the alkalinity all increase, but the yield of biochar decreases. In comparison, the increase of the residence time can increase the ash content and biochar yield, but the heating rate lowers the biochar yield [43]. The porous structure, large specific surface area, high carbon content, and stable physicochemical properties are the main contribution to the 
improvement of biochar composites. The ash in biochars is mainly composed of $\mathrm{K}, \mathrm{Ca}, \mathrm{Mg}$, $\mathrm{Al}, \mathrm{Si}$, etc existing in the form of oxides or salts, which can improve the strength of the polymers acting as rigid particles [44]. The properties of different biochars are shown in Table 2.

Table 2. The main properties of several typical biochars.

\begin{tabular}{|c|c|c|c|c|c|c|c|c|}
\hline Biochars & $\begin{array}{c}\text { Temperatures } \\
\left({ }^{\circ} \mathrm{C}\right)\end{array}$ & $\begin{array}{l}\text { Yield } \\
(\%)\end{array}$ & $\begin{array}{c}\mathrm{S}_{\text {BET }} \\
\left(\mathrm{m}^{2} / \mathrm{g}\right)\end{array}$ & $\mathrm{C}$ & $\mathbf{O}$ & $\mathbf{H}$ & $\mathbf{N}$ & References \\
\hline Corn straw biochar & 400 & 53.94 & 7.15 & 75.14 & 18.92 & 4.56 & 1.38 & [45] \\
\hline Pine saw dust biochar & 550 & & 431.91 & 59.19 & 20.73 & 3.97 & 0.51 & [47] \\
\hline Rice husk biochar & 450 & & 18.58 & 46.56 & 18.58 & 3.54 & 0.85 & [47] \\
\hline Swine manure biochar & 500 & 40.9 & & 33.8 & 14.1 & 2.39 & 2.23 & {$[48]$} \\
\hline Bamboo biochar & 600 & & 181.05 & 82.92 & 5.03 & 2.19 & 0.49 & [49] \\
\hline Grape marc biochar & 500 & 33.8 & 205 & 72.91 & 12.9 & 3.15 & 2.72 & {$[50]$} \\
\hline Palm kernel shell biochar & 750 & 31.15 & 394.53 & 78.95 & 18.27 & 1.79 & 1.00 & [51] \\
\hline
\end{tabular}

\subsection{Biochar Applications}

Charcoal became known to humans as early as the Neolithic Age, and its various applications have led to the exploration of its properties, structures, and characteristics. Figure 2 demonstrates the main current applications of biochars. Adding biochar to soil can increase soil hydraulic capacity, enhance soil fertility, and increase crop yield [52]. Great progress has been made in carbon sequestration, soil pollution control, water pollution control, and air pollution control in the environment field [53]. Additionally, biochar also plays a huge role in energy and fuels, fuel cells, and capacitors due to its high calorific value, high strength, large bulk density, flammability, strong stability, and good conductivity [54,55]. Recently, replacing fibers to reinforce polymers using biochars has attracted attention due to the excellent properties and low costs exhibited in biochar biocomposites. Biochar can increase the degradation rate of the polymeric materials in soil, which is of great significance for environmental protection [56]. In 2013, You et al. used charcoal powder to modify ultra-high molecular weight polyethylene (UHMWPE), and $104.7 \mathrm{MPa}$ of tensile strength was obtained in $70 \%$ loading of the biochars in composites [57].
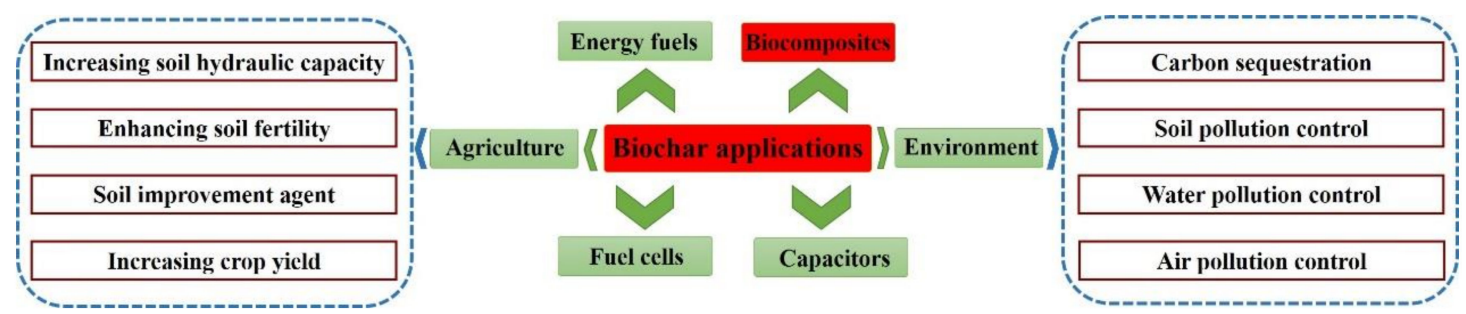

Figure 2. The applications of biochar.

\section{Biochar Composites}

Excellent mechanical and thermal properties are obtained in biochar composites, but high-performance electromagnetic interference shielding and good conductivity are also exhibited due to the unique properties of biochars [58,59]. The fibers are easily degraded at high temperatures (over $200{ }^{\circ} \mathrm{C}$ ) in natural fiber composites, suggesting limitations via manufacturing temperature, but this issue can be overcome by biochars with good thermal stability [60]. Similar to natural fiber composites, current processes such as extrusion, injection molding, and hot pressing can be used for biochar composites, and the equipment involved are extruders, injection machines, and flat-panel vulcanizers, respectively [61]. As stated earlier, all organic materials can be used to produce biochars as fillers for biochar composites, which demonstrates the advantages of feedstock sources. In addition to fillers, matrix selection also plays a key role in the biocomposite system because polymers can protect the 
surface of the fillers from abrasion [8]. Some polymers which can be used for biochar composites are shown in Figure 3. Both thermoplastic and thermoset polymers can be used as a matrix in biochar composites due to the good thermal stability of biochars, but the selectivity of thermoset polymers is narrow in terms of their formability, fluidity, and feedstock source.

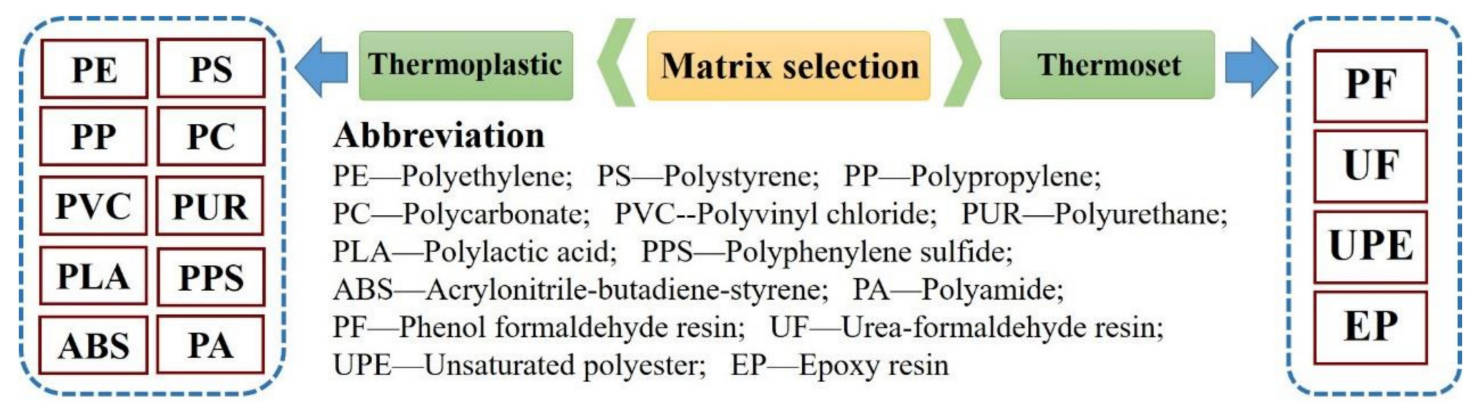

Figure 3. The polymers matrix for biochar composites.

\subsection{Interfacial Characteristics}

The interfacial characteristics, especially the interfacial structure, play an important role in the properties of composites, which are significantly affected by the biochar properties, as stated earlier. Thus, this section discusses the details of interfacial characteristics of biochar composites based on biochar properties, while the ultimate goal is to form the basis for the biochar composite properties. Many documents report that most functional groups were removed after biochar production under heat reaction at high temperatures, and no shifts of polymer peaks were observed with the inclusion of biochars [31,62,63]. This suggested that all the functional groups shown in biochar composites were provided by polymers and no chemical reaction occurred between biochars and polymers. Coincidentally, the lack of polar functional groups, especially hydroxyl, also contributed to a new effect that overcomes the poor compatibility due to different polarities between fibers and polymers in natural fiber composites [26]. Other evidence shows that both the left and right contact angles of biochar composites showed higher values than those of natural fiber composites, indicating the weak hydrophilicity of biochar composites [64]. In the field of composites, X-ray diffraction (XRD) is used to determine the crystal structure of polymer materials, which is also important for characterizing the interface of biochar composites. It is expected that the inclusion of biochars did not change the crystal planes of polymers because of the amorphous nature of biochars, and polymers provided all the diffraction peaks in the biochar composite system. However, the addition of biochar strongly affected the intensity of diffraction peaks, which can be attributed to the loading reduction of crystalline polymers in the composite system [44]. To intuitively characterize the interfacial characteristics of biochar composites, almost all the relevant scholars have explored the microstructure of biochar composites using the scanning electron microscope (SEM), and the results are similar. The microstructure between natural fibers and biochars resulted in the microstructure difference between natural fiber composites and biochar composites. As stated earlier, biochar has a porous structure, and this is the main contributor to the uniqueness of the biochar's composite structure. In the melting process, thermoplastic polymers melted into fluid at high manufacturing temperatures and were pressed into the biochar pores under equipment pressure, and then the special structure formed after cooling, as shown in Figure 4 [65]. Also, liquid thermosetting polymers were dispersed into the biochar pores under mechanical mixing, and then the special structure was molded after heating [66]. This special structure, named physical/mechanical interlocking [31] by Das et al., can efficiently transfer stress, which is evidence that the biochar composites exhibited great mechanical properties. It has been proven that there is no chemical reaction between biochars and polymers. From this viewpoint, the interfacial interaction of the biochar composites can be summed up in two aspects. The first is the physical/mechanical interlocking. After the polymers fill the pores of the biochar, the biochar 
engages with the polymers tightly due to the closer contact. Meanwhile, a portion of the residual stress is stored inside the physical/mechanical interlocks, which strengthens the combination of the biochars and polymers. The second should be attributed to the polymers. Polymers acting as binders make a contribution in terms of bonding the biochar and polymer matrix while gumming different biochar particles. More specifically, Van der Waals' force (VDW) could also provide a solution for the interfacial interaction of biochar composites in terms of molecular attraction. The VDW bond energy is much lower than that of the chemical bond and hydrogen bond, but the large $S_{\mathrm{BET}}$ of biochars greatly increased the contact surface between polymers and biochars, which increased the resultant force of numerous VDWs. Hence, the large concentration of numerous VDWs enhanced the interface bonding force [67].
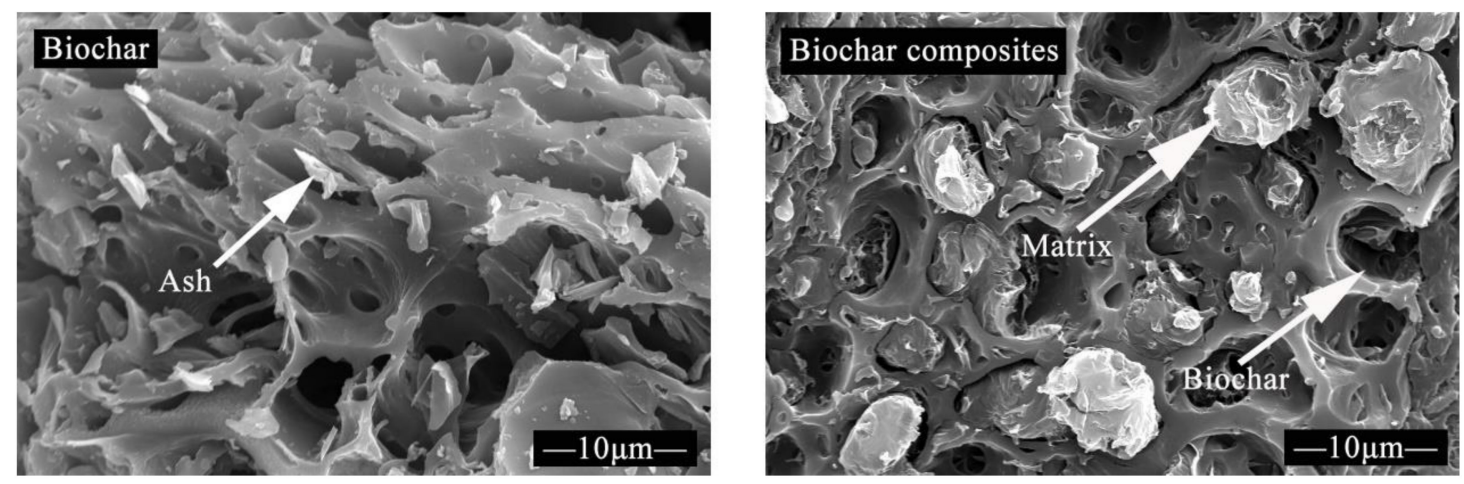

Figure 4. The microstructure of biochar and biochar composites (reproduced with permission from Reference [65]).

\subsection{Mechanical Properties}

Biocomposites are widely desired, and the mechanical properties are the key indicators to evaluate for their applications as these reflect the load-bearing capacity of the biocomposites. Among all the mechanical properties, flexural and tensile properties are the most important and frequently tested. From this viewpoint, the mechanical properties of biochar composites have also been tested and reported in many studies. The mechanical properties of biochar composites are reviewed in Table 3. As stated earlier, the loading of biochars in the biochar composite system is the primary factor for mechanical property analysis. There is no significant difference in the mechanical properties of polymers with low biochar loadings. In contrast, appropriate biochar loading can significantly improve the flexural strength, which is mainly attributed to the physical/mechanical interlocking described above and good dispersion of biochars in polymers which efficiently transfers stress [68]. Similarly, the tensile strength of polymers can also be significantly increased via the addition of appropriate biochar loadings. Besides the aforementioned interfacial structure and good dispersion, the good interfacial compatibility formed by the similar polarity between biochars and polymers also contributes to the increment of the tensile strength [69]. Moreover, both the flexural and tensile moduli increased with the incorporation of biochars, as shown in Table 3. These two increases can be attributed to rigidity shown in biochars; the porous and rigid biochar can efficiently reduce the mobility of the polymer matrix when tensile loading is applied to biochar composites [31]. Nevertheless, excessive biochar loadings (over 70\%) exhibited an adverse effect on the mechanical properties of biochar composites, the same as natural fiber composites, and the aggregation of excessive biochars in the composite system should be responsible for the decrease of the mechanical properties [30]. The aggregation formed by excessive biochars destroyed the interfacial structure, decreased the interfacial bonding, reduced the plasticity, increased the deformability, and introduced weaker mechanical properties. In addition, it was indicated from previous statements that the basic characteristics of biochars are greatly affected by the preparation conditions, especially the temperature, which means that the biochar preparation temperature is crucial to the interfacial structure and mechanical properties of composites, which can be observed 
from Table 3. A report by Bartoli et al. suggested that the mechanical properties increased first and then decreased with the increase of biochar preparation temperatures, and the maximum mechanical properties of biochar composites were obtained at $500 \sim 600{ }^{\circ} \mathrm{C}$ biochar preparation temperatures [70]. Biochar carbonization is incomplete, polarity is relatively high, $\mathrm{S}_{\mathrm{BET}}$ is relatively small, and the porous structure is poor at low biochar preparation temperatures (below $500{ }^{\circ} \mathrm{C}$ ), significantly diminishing the interface compatibility and interface structure and thus decreasing the mechanical properties of biochar composites. Further increase in biochar preparation temperatures to $500 \sim 600{ }^{\circ} \mathrm{C}$ results in the optimal porous structure of biochars and good physical/mechanical interlocking of the biochar composites, which are the main determinants of the best mechanical properties. Although the polarity of biochars is significantly reduced at a range of high temperatures (over $600^{\circ} \mathrm{C}$ ), the porous structure of biochar is also damaged and collapsed, and the physical/mechanical interlocking of biochar composites is compromised [71]. In summary, the mechanical properties depend on the structure of biochars and biochar composites to a great extent. The types of biochars and matrixes also have been found to affect the mechanical properties. A report by Li et al. suggested that adding biochars into UHMWPE can yield composites with excellent tensile strength over $100 \mathrm{MPa}$ [72]. This is related to the high molecular chain entanglement density, high relative molecular weight, and excellent wear resistance of UHMWPE, in addition to the specific properties of biochars. As for the difference caused by the biochar type, it is mainly affected by biochar strength and rigid inorganic oxides attached to biochars [44]. In addition to improved flexural and tensile properties, the incorporation of biochars can also significantly improve the dynamic mechanical properties (stiffness, elasticity, creep resistance, and anti-stress relaxation ability) of polymers which are better than natural fibers $[67,73]$. Compared with natural fibers, the porous structure of biochar can hinder the movement of polymer chains and thus improve the dynamic mechanical properties.

Table 3. The mechanical properties of some biochar composites.

\begin{tabular}{|c|c|c|c|c|c|c|c|c|}
\hline Biochars & Polymers & $\begin{array}{c}\text { Biochar } \\
\text { Temperature } \\
\left({ }^{\circ} \mathrm{C}\right)\end{array}$ & $\begin{array}{c}\text { Biochar } \\
\text { Loading } \\
(\%)\end{array}$ & $\begin{array}{c}\text { Flexural } \\
\text { Strength } \\
\text { (MPa) }\end{array}$ & $\begin{array}{c}\text { Flexural } \\
\text { Modulus } \\
\text { (GPa) }\end{array}$ & $\begin{array}{c}\text { Tensile } \\
\text { Strength } \\
\text { (MPa) }\end{array}$ & $\begin{array}{c}\text { Tensile } \\
\text { Modulus } \\
\text { (GPa) }\end{array}$ & References \\
\hline Date palm biochar & PP & 900 & 15 & & & 34 & 1.36 & [74] \\
\hline Maple tree biochar & $\mathrm{EP}$ & 1000 & 20 & & & 16 & 0.7 & {$[66]$} \\
\hline Rice husk biochar & HDPE & 600 & 50 & 34.95 & 1.76 & 26.25 & 1.87 & [44] \\
\hline Switchgrass biochar & PLA & 500 & 20 & 60 & 3.4 & 54 & 1.9 & {$[28]$} \\
\hline Pine wood biochar & PP & 900 & 30 & 59 & 3 & 29 & 3.48 & [31] \\
\hline Miscanthus biochar & PC/PFA/EP & 500 & 20 & 113 & & 57.9 & 3.2 & [75] \\
\hline Coffee biochar & $\mathrm{EP}$ & 1000 & 15 & & & 25 & 3.26 & [76] \\
\hline $\begin{array}{l}\text { Wasted } \\
\text { cotton biochar }\end{array}$ & $\mathrm{EP}$ & 400 & 5 & & & 23 & 1.6 & [77] \\
\hline Charcoal & UHMWPE & 500 & 70 & & & 102 & & [78] \\
\hline Thuja occidentalis biochar & PP & 700 & 10 & 62 & 2.4 & 32.3 & 2.5 & [62] \\
\hline
\end{tabular}

Acronyms: PP—-polypropylene; EP-epoxy resin; HDPE—high-density polyethylene; PLA—polylactic acid; UHMWPE-ultra-high molecular weight polyethylene; PC-polycarbonate; PFA-poly(furfuryl alcohol); LLDPE-linear low-density polyethylene.

\subsection{Thermal Properties}

The good thermal properties of biocomposites are desired for many applications, especially for use in building materials and outdoor decorations. Finding the balance among mechanical properties, thermal properties, and environmental protection is crucial for the development of biocomposites in the future, and biochar composites are no exception to this rule. In order to meet the requirements for high-quality biocomposites, thermal analyses including thermogravimetric analysis (TGA), flame retardant testing, and differential scanning calorimeter (DSC) analysis were used to characterize the 
thermal properties for the safety design of biochar composites. As mentioned early, the biochar has high thermal stability, with evidence that a relatively smooth thermogravimetric curve can be obtained in biochar indicating no degradation except for water loss due to the increase in temperatures [80]. Good thermal stability is expected to help biochar composites obtain better thermal properties. Many scholars compared the TGA of polymers and the biochar-added composites and observed rather surprising results. The mass-loss rate (DTG) curve exhibited a shift of peaks to higher temperatures in biochar composites in comparison to neat polymer, indicating that the addition of biochars delayed the thermal decomposition rate of polymers, and this is the evidence that the thermal stable biochar improved the thermal properties of polymers [81]. In contrast, a new peak appeared at around $300{ }^{\circ} \mathrm{C}$ in the TG curve of natural-fiber-added composites due to the fact that the hemicellulose and cellulose in natural fibers were degraded ahead of time at low temperatures [82]. Thus, another advantage of biochars over natural fibers is that the addition of the natural fiber decreased the thermal properties of polymers. On the other hand, neat polymers have less thermal stability, with the evidence that little residue is yielded in the DTG curve of polymers due to the almost complete degradation. From this viewpoint, the addition of biochars significantly affected the thermal properties of polymers in terms of the high amount of residue produced [31]. Therefore, the thermal stable biochar can efficiently improve the thermal stability in terms of delaying the decomposition rate with increased residue content. As stated earlier, fire resistance is always a crucial factor in the application of biocomposites. Accordingly, cone calorimetry and the limiting oxygen index are used to characterize the fire resistance of biocomposites. The literature has shown that the flammability of natural fiber composites failed to meet the requirements. Although the introduction of flame retardants is proven to be effective, the increase in costs should not be ignored. In the meantime, the fire resistance is also explored and reported in the resultant composites prepared by replacing natural fibers using biochars. The flame-retardant tests by Das et al. [83] and Zhang et al. [44] showed that biochar addition reduced the peak of the heat release and increased the limiting oxygen index of neat polymers, indicating the improvement of fire resistance. The flame-retardant mechanism of the biochars can be analyzed in two aspects. First of all, the thermal-stable biochar in the composite system acted as the insulation barrier and blocked the contact between polymers and air [83]. The other reason can be attributed to the increased ash content produced from biochar preparation. The ash made of nonflammable inorganic matter can be considered as a flame retardant, and it delays the combustion of polymers [84]. Furthermore, DSC could also provide other evidence for the better thermal properties of biochar composites via their melting and crystallization behavior. Studies by Li et al. and Pan et al. have shown that a slight decrease in melting temperature can be observed in biochar composites compared to neat polymers, and this suggested that the inclusion of biochars decreased the lamella thickness and crystals $[67,85]$. The interesting result is the exothermic crystallization which occurred in the cooling phase. Adding biochars significantly increased the crystallization temperature of polymers, indicating that the addition of biochars promoted the crystallization of polymers, which is important for shortening the molding cycle of the biochar composites. Biochars acted as points from where crystal growth was initiated, and the nucleation effect of them accelerated the crystallization of polymers in composites $[69,86]$, which is similar to the effect of natural fiber particles. Besides, it can be seen in Table 4 that the crystallinity of biochar composites is also reduced after the incorporation of biochars, and this reduction can be attributed to the structure of the biochars. The pores of biochars restrict the movement of polymer chains and hinder the transition of polymer segments to their crystal form [74]. 
Table 4. The melting and crystallization behavior of some biochar composites.

\begin{tabular}{|c|c|c|c|c|c|}
\hline Samples & Biochar Loading (\%) & $\mathrm{T}_{\mathrm{m}}\left({ }^{\circ} \mathrm{C}\right)$ & $\mathrm{T}_{\mathrm{c}}\left({ }^{\circ} \mathrm{C}\right)$ & $X_{c}(\%)$ & References \\
\hline $\mathrm{PP}$ & 0 & 166.78 & 120.97 & 43.0 & \multirow{2}{*}[74]{} \\
\hline Date palm biochar added & 5 & 164.4 & 121.34 & 33.42 & \\
\hline Nylon & 0 & 217.9 & 196.4 & 32.67 & \multirow{2}{*}{ [79] } \\
\hline Miscanthus biochar added & 20 & 217.2 & 194.9 & 30.04 & \\
\hline PLA & 0 & 159.84 & 129.09 & 49.50 & \multirow{2}{*}{ [69] } \\
\hline Bamboo biochar added & 7.5 & 156.68 & 135.11 & 13.90 & \\
\hline $\begin{array}{c}\text { PLA } \\
\text { Ultrafine bamboo-char } \\
\text { added }\end{array}$ & $\begin{array}{c}0 \\
40\end{array}$ & $\begin{array}{l}149.7 \\
142.2\end{array}$ & $\begin{array}{c}126.3 \\
94.4\end{array}$ & $\begin{array}{c}1.09 \\
22.06\end{array}$ & [87] \\
\hline PLA & 0 & 169.5 & 102.5 & 13.9 & \multirow{2}{*}{ [88] } \\
\hline Coffee biochar added & 2.5 & 168.3 & 96.9 & 23.3 & \\
\hline PVA & 0 & 214.96 & 290.11 & 57.70 & \multirow{2}{*}{ [89] } \\
\hline Hard wood biochar & 10 & 192.82 & 337.10 & 41.88 & \\
\hline $\mathrm{PP}$ & 0 & 165 & 117 & 53 & \multirow{2}{*}{ [90] } \\
\hline Tea leaves biochar added & 30 & 165 & 128 & 53 & \\
\hline UHMWPE & 0 & 135.1 & 119.6 & & \multirow{2}{*}{ [67] } \\
\hline Bamboo biochar added & 80 & 132.8 & 122.8 & & \\
\hline HDPE & 0 & 131 & 120 & & \multirow{2}{*}{ [63] } \\
\hline Poplar biochar added & 70 & 130 & 123 & & \\
\hline
\end{tabular}

Acronyms: PP—polypropylene; PLA—-polylactic acid; PVA—polyvinyl alcohol; UHMWPE—ultra-high molecular weight polyethylene; HDPE—-high-density polyethylene; $\mathrm{T}_{\mathrm{m}}$ - melting temperature; $\mathrm{T}_{\mathrm{c}}$-crystallization temperature; $\mathrm{X}_{\mathrm{c}}$-crystallinity.

\subsection{Electrical Properties}

Natural fiber composites are notoriously non-conducive due to the non-conductive properties of polymers and natural fibers, which are unfavorable for composite functionalization. Table 5 demonstrates a review of conductivity in biochar composites. The biochar is rich in carbon with highly stable physicochemical properties. The increase of aromatization and graphitization is achieved with increasing biochar preparation temperatures [91]. These properties give biochar good conductivity, and the introduction of biochars to polymers is expected to provide the possibility of preparing conductive composites. Lots of studies have been done to explore the electrical properties of biochar composites, as illustrated in Table 5. Nan et al. [92] studied the electrical response behavior of poly (vinyl alcohol) (PVA)/wood-derived biochar composites. They found that the increase of biochar loadings improved the conductivity and significantly decreased the electrical resistance of PVA/biochar composites. The increasing biochar content contributed to the conductive paths in the composite system. Electromagnetic interference shielding (EMISE) is used to measure the barrier effect of materials on electromagnetic waves and characterize electrical properties. Surprisingly, $10 \mathrm{~dB}$ and $48.7 \mathrm{~dB}$ of EMISE were obtained in $20 \%$ biochar composites and $80 \%$ biochar composites reported by Savi et al. [93] and Li et al. [58], respectively, which indicates that biochars facilitated the excellent EMISE performance in the composite system. This can be attributed to the conversion and dissipation of the electromagnetic wave energy to electricity and heat energy due to the good conductivity, porous structure, and large $\mathrm{S}_{\mathrm{BET}}$ of biochars [94]. The conductivity of biochar composites is mainly determined by two factors, i.e., biochar preparation temperatures and biochar loadings, as shown in Table 5. The conductivity increases as these two things increase. Increasing the preparation temperatures resulted in the enlargement of the aromatic region and increased the conductivity of biochars [76,95]. Increasing biochar loadings can facilitate the conductive chains and conductive clusters inside composites [96,97]. Biochar composites compensated for the defects of the electrical properties of natural fiber composites, which is crucial for the wide application of biocomposites. 
Table 5. Conductivity of some biochar composites.

\begin{tabular}{|c|c|c|c|c|}
\hline Composites Samples & $\begin{array}{c}\text { Biochar } \\
\text { Temperature }\left({ }^{\circ} \mathrm{C}\right)\end{array}$ & $\begin{array}{c}\text { Biochar Loading } \\
(\%)\end{array}$ & $\begin{array}{l}\text { Conductivity } \\
(\mathrm{S} / \mathrm{cm})\end{array}$ & References \\
\hline Bamboo biochar/UHMWPE & 1000 & 7 & $1.1 \times 10^{-2}$ & {$[72]$} \\
\hline Coffee biochar/EP & 600 & 5 & 2 & [76] \\
\hline Coffee biochar/EP & 1000 & 20 & $2.02 \times 10^{2}$ & [76] \\
\hline Pine biochar/UHMWPE & 1100 & 50 & $2 \times 10^{-1}$ & [78] \\
\hline Plastic waste biochar/EP & 450 & 5 & $6.54 \times 10^{-8}$ & [97] \\
\hline Pine cone biochar/EP & 450 & 25 & $6.07 \times 10^{-3}$ & [97] \\
\hline Maple wood biochar/EP & 950 & 20 & $1.3 \times 10^{1}$ & [27] \\
\hline Apple biochar/UHMWPE & 700 & 70 & $1.7 \times 10^{-3}$ & [29] \\
\hline Apple biochar/UHMWPE & 900 & 70 & $8.2 \times 10^{-2}$ & [29] \\
\hline Miscanthus biochar/EP & 650 & 20 & $2 \times 10^{1}$ & [59] \\
\hline Miscanthus biochar/EP & 750 & 20 & $2.75 \times 10^{2}$ & [59] \\
\hline PET biochar/oligomers & 450 & 50 & $1 \times 10^{-2}$ & [98] \\
\hline
\end{tabular}

\section{Conclusion and Outlook}

This paper gives an overview of biocomposites made from biochars that are produced from organic solid wastes. The interfacial characteristics and typical properties of biochar composites are analyzed and discussed. Compared with natural fiber composites, biochar composites exhibited better mechanical, thermal, and electrical properties due to the special nature, i.e., porous structure, large specific surface area, high thermal stability, and good conductivity of biochars. Moreover, the abundance of biochar feedstock sources and the removal of additives in composites can significantly lower the costs of biochar composites. The balance achieved by the properties and costs justifies the renewability and sustainability of the biocomposites, which is crucial for their wide applications across many areas. Nevertheless, further development is required for biochar composites to meet the great challenges of biocomposites and their applications.

Biochar composites have excellent mechanical, thermal, and electrical properties with good water and wear resistance which paves the way for their use. Other properties, especially aging resistance, weather resistance, antibacterial, and sound absorption, are also desired for many biocomposites. As for the outlook of biochar composites, some suggestions are made and shown in Figure 5. The multifunctionalization of biocomposites must be studied and developed to respond to the growing requirements for various applications. Meanwhile, high-strength biocomposites are required in some specific applications, and there is a need to enhance the strength of biochar composites. The addition of rigid particles such as inorganic oxide, carbon fiber, mineral fiber, synthetic fiber, and so on can be considered and studied, and the synergy mechanisms between biochars and rigid particles should also be considered, as they are important for the strength enhancement of biochar composites. As stated above, the porous structure and large specific surface area are the main reasons for the good mechanical properties. From this viewpoint, further expansion of the biochar structure and specific surface area via procedures such as activation can be another target for establishing a correlation between the pore characteristics of biochars and the mechanical properties of biochar composites. Additionally, the structural design of biochar composites is a key factor to be considered in practical applications, and the future development of biochar composites should focus on performance and structure integration design to meet social needs for material design. Furthermore, the premise of biochar composite development and application is to improve production efficiency, which requires cooperation between the production system and production equipment. Many factors, i.e., the storage and transportation of organic solid wastes, large scale carbonization equipment, and composites workshops should be considered in detail. The final thought is the recovery of biochar composites, and this is crucial in the production life-cycle system. The specifics of polymers and biochars yield the recyclability of biochar composites, which achieve a balance in terms of protecting the environment and conserving resources. 
Overall, the future development potential of biochar composites is very positive, with new designs anticipated to solve significant challenges.

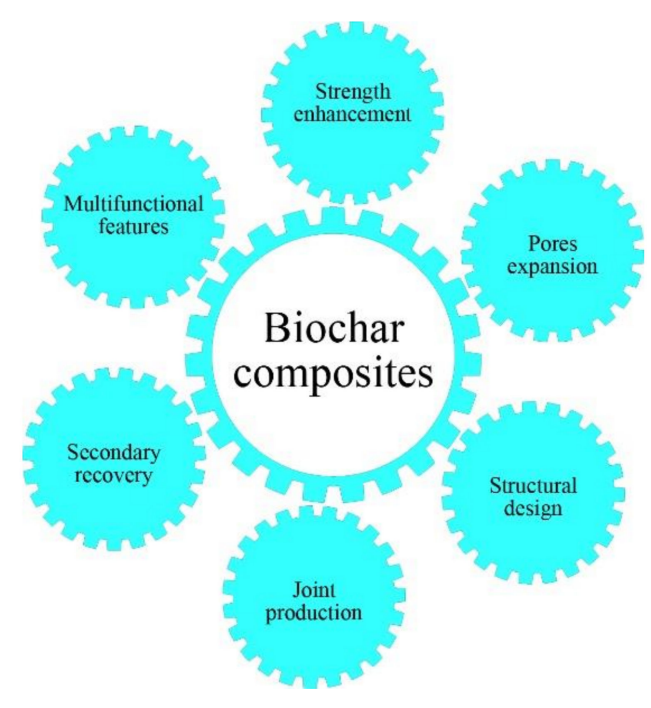

Figure 5. Suggestions for the future development of biochar composites.

Author Contributions: Conceptualization, Q.Z. and H.C.; writing-Original draft; W.Y. and H.L. (Hanwu Lei); Supervision, Writing-Review and editing; H.L. (Haolu Liu), W.W. and R.R. All authors have read and agreed to the published version of the manuscript.

Funding: The authors appreciate that this work was financially supported by the Natural Science Foundation of Shandong Province of China (No. ZR2019MEE036); the Agriculture and Food Research Initiative Competitive Grant (No. 2016-67021-24533) from the National Institute of Food and Agriculture, United States Department of Agriculture; the National Key Research and Development Program of China (No. 2018YFD1101001); the distinguished expert of the Taishan scholars Shandong province project and the higher education superior discipline team training program of Shandong province.

Conflicts of Interest: The authors declare no conflict of interest.

\section{References}

1. Das, S.; Lee, S.-H.; Kumar, P.; Kim, K.-H.; Lee, S.S.; Bhattacharya, S.S. Solid waste management: Scope and the challenge of sustainability. J. Clean. Prod. 2019, 228, 658-678. [CrossRef]

2. Al-Hamamre, Z.; Saidan, M.; Hararah, M.; Rawajfeh, K.; Alkhasawneh, H.E.; Al-Shannag, M. Wastes and biomass materials as sustainable-renewable energy resources for Jordan. Renew. Sustain. Energy Rev. 2017, 67, 295-314. [CrossRef]

3. Sarkar, P.; Chourasia, R. Bioconversion of organic solid wastes into biofortified compost using a microbial consortium. Int. J. Recycl. Org. Waste Agric. 2017, 6, 321-334. [CrossRef]

4. Mishra, P.; Balachandar, G.; Das, D. Improvement in biohythane production using organic solid waste and distillery effluent. Waste Manag. (Oxford) 2017, 66, 70-78. [CrossRef]

5. Li, X.; Mei, Q.; Dai, X.; Ding, G. Effect of anaerobic digestion on sequential pyrolysis kinetics of organic solid wastes using thermogravimetric analysis and distributed activation energy model. Bioresour. Technol. 2017, 227, 297-307. [CrossRef]

6. Zhang, Q.; Khan, M.U.; Lin, X.; Yi, W.; Lei, H. Green-composites produced from waste residue in pulp and paper industry: A sustainable way to manage industrial wastes. J. Clean. Prod. 2020, 262, 121251. [CrossRef]

7. Fox, J.A.; Stacey, N.T. Process targeting: An energy based comparison of waste plastic processing technologies. Energy 2019, 170, 273-283. [CrossRef]

8. Pickering, K.L.; Efendy, M.A.; Le, T.M. A review of recent developments in natural fibre composites and their mechanical performance. Composites Part A Appl. Sci. Manuf. 2016, 83, 98-112. [CrossRef] 
9. Sepe, R.; Bollino, F.; Boccarusso, L.; Caputo, F. Influence of chemical treatments on mechanical properties of hemp fiber reinforced composites. Compos. Part B Eng. 2018, 133, 210-217. [CrossRef]

10. Mittal, V.; Saini, R.; Sinha, S. Natural fiber-mediated epoxy composites-A review. Compos. Part B Eng. 2016, 99, 425-435. [CrossRef]

11. Zhang, Q.; Li, Y.; Cai, H.; Lin, X.; Yi, W.; Zhang, J. Properties comparison of high density polyethylene composites filled with three kinds of shell fibers. Results Phys. 2019, 12, 1542-1546. [CrossRef]

12. Lau, K.-T.; Hung, P.-Y.; Zhu, M.-H.; Hui, D. Properties of natural fibre composites for structural engineering applications. Compos. Part B Eng. 2018, 136, 222-233. [CrossRef]

13. Essabir, H.; Bensalah, M.O.; Rodrigue, D.; Bouhfid, R.; el kacem Qaiss, A. Biocomposites based on argan nut shell and a polymer matrix: Effect of filler content and coupling agent. Carbohydr. Polym. 2016, 143, 70-83. [CrossRef] [PubMed]

14. Oguz, O.; Simsek, E.; Kosak Soz, C.; Kasli Heinz, O.; Yilgor, E.; Yilgor, I.; Menceloglu, Y.Z. Effect of filler content on the structure-property behavior of poly (ethylene oxide) based polyurethaneurea-silica nanocomposites. Polymer Eng. Sci. 2018, 58, 1097-1107. [CrossRef]

15. Kaewkuk, S.; Sutapun, W.; Jarukumjorn, K. Effects of interfacial modification and fiber content on physical properties of sisal fiber/polypropylene composites. Compos. Part B Eng. 2013, 45, 544-549. [CrossRef]

16. Kalia, S.; Thakur, K.; Celli, A.; Kiechel, M.A.; Schauer, C.L. Surface modification of plant fibers using environment friendly methods for their application in polymer composites, textile industry and antimicrobial activities: A review. J. Environ. Chem. Eng. 2013, 1, 97-112. [CrossRef]

17. Ogawa, T.; Mukai, H.; Osawa, S. Improvement of the mechanical properties of an ultrahigh molecular weight polyethylene fiber/epoxy composite by corona-discharge treatment. J. Appl. Polym. Sci. 2001, 79, 1162-1168. [CrossRef]

18. Yan, L.; Chouw, N.; Huang, L.; Kasal, B. Effect of alkali treatment on microstructure and mechanical properties of coir fibres, coir fibre reinforced-polymer composites and reinforced-cementitious composites. Constr. Build. Mater. 2016, 112, 168-182. [CrossRef]

19. Pasquini, D.; de Morais Teixeira, E.; da Silva Curvelo, A.A.; Belgacem, M.N.; Dufresne, A. Surface esterification of cellulose fibres: Processing and characterisation of low-density polyethylene/cellulose fibres composites. Compos. Sci. Technol. 2008, 68, 193-201. [CrossRef]

20. Saha, P.; Chowdhury, S.; Roy, D.; Adhikari, B.; Kim, J.K.; Thomas, S. A brief review on the chemical modifications of lignocellulosic fibers for durable engineering composites. Polym. Bull. 2016, 73, 587-620. [CrossRef]

21. Michałowski, S.; Prociak, A.; Zajchowski, S.; Tomaszewska, J.; Mirowski, J. Porous product with reduced apparent density keeps good mechanical properties. Extruded composites of poly (vinyl chloride) blown under microwave irradiation. Polym. Test. 2017, 64, 229-234. [CrossRef]

22. Alam, A.; Wan, C.; McNally, T. Surface amination of carbon nanoparticles for modification of epoxy resins: Plasma-treatment vs. wet-chemistry approach. Eur. Polym. J. 2017, 87, 422-448. [CrossRef]

23. Wu, D.; Wang, X.; Song, Y.; Jin, R. Nanocomposites of poly (vinyl chloride) and nanometric calcium carbonate particles: Effects of chlorinated polyethylene on mechanical properties, morphology, and rheology. J. Appl. Polym. Sci. 2004, 92, 2714-2723. [CrossRef]

24. Wu, N.; Lang, S. Flame retardancy and toughness modification of flame retardant polycarbonate/acrylonitrile-butadiene-styrene/AHP composites. Polym. Degrad. Stab. 2016, 123, 26-35. [CrossRef]

25. Mishra, S.; Naik, J.; Patil, Y. The compatibilising effect of maleic anhydride on swelling and mechanical properties of plant-fiber-reinforced novolac composites. Compos. Sci. Technol. 2000, 60, 1729-1735. [CrossRef]

26. Zhang, Q.; Lei, H.; Cai, H.; Han, X.; Lin, X.; Qian, M.; Zhao, Y.; Huo, E.; Villota, E.M.; Mateo, W. Improvement on the properties of microcrystalline cellulose/polylactic acid composites by using activated biochar. J. Clean. Prod. 2020, 252, 119898. [CrossRef]

27. Khan, A.; Savi, P.; Quaranta, S.; Rovere, M.; Giorcelli, M.; Tagliaferro, A.; Rosso, C.; Jia, C.Q. Low-cost carbon fillers to improve mechanical properties and conductivity of epoxy composites. Polymers 2017, 9, 642. [CrossRef]

28. Bajwa, D.S.; Adhikari, S.; Shojaeiarani, J.; Bajwa, S.G.; Pandey, P.; Shanmugam, S.R. Characterization of bio-carbon and ligno-cellulosic fiber reinforced bio-composites with compatibilizer. Constr. Build. Mater. 2019, 204, 193-202. [CrossRef] 
29. Li, S.; Li, X.; Deng, Q.; Li, D. Three kinds of charcoal powder reinforced ultra-high molecular weight polyethylene composites with excellent mechanical and electrical properties. Mater. Design 2015, 85, 54-59. [CrossRef]

30. Behazin, E.; Misra, M.; Mohanty, A.K. Compatibilization of toughened polypropylene/biocarbon biocomposites: A full factorial design optimization of mechanical properties. Polym. Test. 2017, 61, 364-372. [CrossRef]

31. Das, O.; Bhattacharyya, D.; Hui, D.; Lau, K.-T. Mechanical and flammability characterisations of biochar/polypropylene biocomposites. Compos. Part B Eng. 2016, 106, 120-128. [CrossRef]

32. Li, Z.; Reimer, C.; Wang, T.; Mohanty, A.K.; Misra, M. Thermal and mechanical properties of the biocomposites of miscanthus biocarbon and poly (3-Hydroxybutyrate-co-3-Hydroxyvalerate)(PHBV). Polymers 2020, 12, 1300. [CrossRef] [PubMed]

33. Zhang, Q.; Xu, H.; Lu, W.; Zhang, D.; Ren, X.; Yu, W.; Wu, J.; Zhou, L.; Han, X.; Yi, W. Properties evaluation of biochar/high-density polyethylene composites: Emphasizing the porous structure of biochar by activation. Sci. Total Environ. 2020, 737, 139770. [CrossRef] [PubMed]

34. Bridgwater, A.V. Review of fast pyrolysis of biomass and product upgrading. Biomass Bioenergy 2012, 38, 68-94. [CrossRef]

35. Arbogast, S.; Bellman, D.; Paynter, J.; Wykowski, J. Advanced biofuels from pyrolysis oil ... Opportunities for cost reduction. Fuel Process. Technol. 2013, 106, 518-525. [CrossRef]

36. Ingram, L.; Mohan, D.; Bricka, M.; Steele, P.; Strobel, D.; Crocker, D.; Mitchell, B.; Mohammad, J.; Cantrell, K.; Pittman, C.U., Jr. Pyrolysis of wood and bark in an auger reactor: Physical properties and chemical analysis of the produced bio-oils. Energy Fuels 2008, 22, 614-625. [CrossRef]

37. Di Blasi, C. Heat transfer mechanisms and multi-step kinetics in the ablative pyrolysis of cellulose. Chem. Eng. Sci. 1996, 51, 2211-2220. [CrossRef]

38. Li, Z.; Li, N.; Yi, W.; Fu, P.; Li, Y.; Bai, X. Design and operation of a down-tube reactor demonstration plant for biomass fast pyrolysis. Fuel Process. Technol. 2017, 161, 182-192. [CrossRef]

39. Lappas, A.; Dimitropoulos, V.; Antonakou, E.; Voutetakis, S.; Vasalos, I. Design, construction, and operation of a transported fluid bed process development unit for biomass fast pyrolysis: Effect of pyrolysis temperature. Ind. Eng. Chem. Res. 2008, 47, 742-747. [CrossRef]

40. Zhao, X.; Wang, M.; Liu, H.; Li, L.; Ma, C.; Song, Z. A microwave reactor for characterization of pyrolyzed biomass. Bioresour. Technol. 2012, 104, 673-678. [CrossRef]

41. Gonzaga, M.I.S.; Mackowiak, C.L.; Comerford, N.B.; da Veiga Moline, E.F.; Shirley, J.P.; Guimaraes, D.V. Pyrolysis methods impact biosolids-derived biochar composition, maize growth and nutrition. Soil Tillage Res. 2017, 165, 59-65. [CrossRef]

42. Cha, J.S.; Park, S.H.; Jung, S.-C.; Ryu, C.; Jeon, J.-K.; Shin, M.-C.; Park, Y.-K. Production and utilization of biochar: A review. J. Ind. Eng. Chem. 2016, 40, 1-15. [CrossRef]

43. Zhao, B.; O'Connor, D.; Zhang, J.; Peng, T.; Shen, Z.; Tsang, D.C.; Hou, D. Effect of pyrolysis temperature, heating rate, and residence time on rapeseed stem derived biochar. J. Clean. Prod. 2018, 174, 977-987. [CrossRef]

44. Zhang, Q.; Zhang, D.; Xu, H.; Lu, W.; Ren, X.; Cai, H.; Lei, H.; Huo, E.; Zhao, Y.; Qian, M. Biochar filled high-density polyethylene composites with excellent properties: Towards maximizing the utilization of agricultural wastes. Ind. Crops Prod. 2020, 146, 112185. [CrossRef]

45. Fu, P.; Yi, W.; Li, Z.; Bai, X.; Wang, L. Evolution of char structural features during fast pyrolysis of corn straw with solid heat carriers in a novel V-shaped down tube reactor. Energy Convers. Manag. 2017, 149, 570-578. [CrossRef]

46. Fu, P.; Bai, X.; Yi, W.; Li, Z.; Li, Y. Fast pyrolysis of wheat straw in a dual concentric rotary cylinder reactor with ceramic balls as recirculated heat carrier. Energy Convers. Manag. 2018, 171, 855-862. [CrossRef]

47. Pariyar, P.; Kumari, K.; Jain, M.K.; Jadhao, P.S. Evaluation of change in biochar properties derived from different feedstock and pyrolysis temperature for environmental and agricultural application. Sci. Total Environ. 2020, 713, 136433. [CrossRef]

48. Rodriguez, J.A.; Lustosa Filho, J.F.; Melo, L.C.A.; de Assis, I.R.; de Oliveira, T.S. Influence of pyrolysis temperature and feedstock on the properties of biochars produced from agricultural and industrial wastes. J. Anal. Appl. Pyrolysis 2020, 149, 104839. [CrossRef] 
49. Wang, H.; Wang, X.; Cui, Y.; Xue, Z.; Ba, Y. Slow pyrolysis polygeneration of bamboo (Phyllostachys pubescens): Product yield prediction and biochar formation mechanism. Bioresour. Technol. 2018, 263, 444-449. [CrossRef]

50. Ferjani, A.I.; Jeguirim, M.; Jellali, S.; Limousy, L.; Courson, C.; Akrout, H.; Thevenin, N.; Ruidavets, L.; Muller, A.; Bennici, S. The use of exhausted grape marc to produce biofuels and biofertilizers: Effect of pyrolysis temperatures on biochars properties. Renew. Sustain. Energy Rev. 2019, 107, 425-433. [CrossRef]

51. Ma, Z.; Yang, Y.; Ma, Q.; Zhou, H.; Luo, X.; Liu, X.; Wang, S. Evolution of the chemical composition, functional group, pore structure and crystallographic structure of bio-char from palm kernel shell pyrolysis under different temperatures. J. Anal. Appl. Pyrolysis 2017, 127, 350-359. [CrossRef]

52. Emma, M. Black is the new green. Nature 2006, 442, 624-626.

53. Wang, D.; Jiang, P.; Zhang, H.; Yuan, W. Biochar production and applications in agro and forestry systems: A review. Sci. Total Environ. 2020, 723, 137775. [CrossRef] [PubMed]

54. Mohan, D.; Abhishek, K.; Sarswat, A.; Patel, M.; Singh, P.; Pittman, C.U. Biochar production and applications in soil fertility and carbon sequestration-a sustainable solution to crop-residue burning in India. RSC Adv. 2018, 8, 508-520. [CrossRef]

55. Sun, L.; Zhang, Z.; Sun, Y.'; Yang, G. One-pot pyrolysis route to Fe- N-Doped carbon nanosheets with outstanding electrochemical performance as cathode materials for microbial fuel cell. J. Agric. Biol. Eng. 2020. [CrossRef]

56. Gonçalves, S.P.c.C.; Strauss, M.; Martinez, D.S.f.T. The positive fate of biochar addition to soil in the degradation of PHBV-Silver nanoparticle composites. Environ. Sci. Technol. 2018, 52, 13845-13853. [CrossRef]

57. You, Z.; Li, D. The dynamical viscoelasticity and tensile property of new highly filled charcoal powder/ultra-high molecular weight polyethylene composites. Mater. Lett. 2013, 112, 197-199. [CrossRef]

58. Li, S.; Huang, A.; Chen, Y.-J.; Li, D.; Turng, L.-S. Highly filled biochar/ultra-high molecular weight polyethylene/linear low density polyethylene composites for high-performance electromagnetic interference shielding. Compos. Part B Eng. 2018, 153, 277-284. [CrossRef]

59. Giorcelli, M.; Savi, P.; Khan, A.; Tagliaferro, A. Analysis of biochar with different pyrolysis temperatures used as filler in epoxy resin composites. Biomass Bioenergy 2019, 122, 466-471. [CrossRef]

60. Bartoli, M.; Giorcelli, M.; Jagdale, P.; Rovere, M.; Tagliaferro, A. A Review of Non-Soil Biochar Applications. Materials 2020, 13, 261. [CrossRef]

61. Summerscales, J.; Dissanayake, N.P.; Virk, A.S.; Hall, W. A review of bast fibres and their composites. Part 1-Fibres as reinforcements. Compos. Part A Appl. Sci. Manuf. 2010, 41, 1329-1335. [CrossRef]

62. Gezahegn, S.; Lai, R.; Huang, L.; Chen, L.; Huang, F.; Blozowski, N.; Thomas, S.C.; Sain, M.; Tjong, J.; Jaffer, S. Porous graphitic biocarbon and reclaimed carbon fiber derived environmentally benign lightweight composites. Sci. Total Environ. 2019, 664, 363-373. [CrossRef] [PubMed]

63. Zhang, Q.; Khan, M.U.; Lin, X.; Cai, H.; Lei, H. Temperature varied biochar as a reinforcing filler for high-density polyethylene composites. Compos. Part B Eng. 2019, 175, 107151. [CrossRef]

64. Das, O.; Sarmah, A.K.; Bhattacharyya, D. Biocomposites from waste derived biochars: Mechanical, thermal, chemical, and morphological properties. Waste Manag. (Oxford) 2016, 49, 560-570. [CrossRef] [PubMed]

65. Zhang, Q.; Yi, W.; Li, Z.; Wang, L.; Cai, H. Mechanical properties of rice husk biochar reinforced high density polyethylene composites. Polymers 2018, 10, 286. [CrossRef]

66. Giorcelli, M.; Khan, A.; Pugno, N.M.; Rosso, C.; Tagliaferro, A. Biochar as a cheap and environmental friendly filler able to improve polymer mechanical properties. Biomass Bioenergy 2019, 120, 219-223. [CrossRef]

67. Li, S.; Wang, H.; Chen, C.; Li, X.; Deng, Q.; Li, D. Mechanical, electrical, and thermal properties of highly filled bamboo charcoal/ultra-high molecular weight polyethylene composites. Polym. Compos. 2018, 39, E1858-E1866. [CrossRef]

68. Ikram, S.; Das, O.; Bhattacharyya, D. A parametric study of mechanical and flammability properties of biochar reinforced polypropylene composites. Compos. Part A Appl. Sci. Manuf. 2016, 91, 177-188. [CrossRef]

69. Ho, M.-P.; Lau, K.-T.; Wang, H.; Hui, D. Improvement on the properties of polylactic acid (PLA) using bamboo charcoal particles. Compos. Part B Eng. 2015, 81, 14-25. [CrossRef]

70. Bartoli, M.; Nasir, M.A.; Jagdale, P.; Passaglia, E.; Spiniello, R.; Rosso, C.; Giorcelli, M.; Rovere, M.; Tagliaferro, A. Influence of pyrolytic thermal history on olive pruning biochar and related epoxy composites mechanical properties. J. Compos. Mater. 2019, 54, 1863-1873. [CrossRef] 
71. Zhang, Q.; Zhang, D.; Lu, W.; Khan, M.U.; Xu, H.; Yi, W.; Lei, H.; Huo, E.; Qian, M.; Zhao, Y. Production of high-density polyethylene biocomposites from rice husk biochar: Effects of varying pyrolysis temperature. Sci. Total Environ. 2020, 738, 139910. [CrossRef] [PubMed]

72. Li, S.; Li, X.; Chen, C.; Wang, H.; Deng, Q.; Gong, M.; Li, D. Development of electrically conductive nano bamboo charcoal/ultra-high molecular weight polyethylene composites with a segregated network. Compos. Sci. Technol. 2016, 132, 31-37. [CrossRef]

73. Zhang, Q.; Cai, H.; Ren, X.; Kong, L.; Liu, J.; Jiang, X. The dynamic mechanical analysis of highly filled rice husk biochar/high-density polyethylene composites. Polymers 2017, 9, 628. [CrossRef] [PubMed]

74. Poulose, A.M.; Elnour, A.Y.; Anis, A.; Shaikh, H.; Al-Zahrani, S.; George, J.; Al-Wabel, M.I.; Usman, A.R.; Ok, Y.S.; Tsang, D.C. Date palm biochar-polymer composites: An investigation of electrical, mechanical, thermal and rheological characteristics. Sci. Total Environ. 2018, 619, 311-318. [CrossRef]

75. Mashouf Roudsari, G.; Mohanty, A.K.; Misra, M. A statistical approach to develop biocomposites from epoxy resin, poly (furfuryl alcohol), poly (propylene carbonate), and biochar. J. Appl. Polym. Sci. 2017, 134, 45307. [CrossRef]

76. Giorcelli, M.; Bartoli, M. Development of coffee biochar filler for the production of electrical conductive reinforced plastic. Polymers 2019, 11, 1916. [CrossRef]

77. Bartoli, M.; Rosso, C.; Giorcelli, M.; Rovere, M.; Jagdale, P.; Tagliaferro, A.; Chae, M.; Bressler, D.C. Effect of incorporation of microstructured carbonized cellulose on surface and mechanical properties of epoxy composites. J. Appl. Polym. Sci. 2019, 137, 48896. [CrossRef]

78. Li, S.; Li, D. Electrically conductive charcoal powder/ultrahigh molecular weight polyethylene composites. Mater. Lett. 2014, 137, 409-412. [CrossRef]

79. Ogunsona, E.O.; Misra, M.; Mohanty, A.K. Impact of interfacial adhesion on the microstructure and property variations of biocarbons reinforced nylon 6 biocomposites. Compos. Part A Appl. Sci. Manuf. 2017, 98, 32-44. [CrossRef]

80. Conti, R.; Fabbri, D.; Vassura, I.; Ferroni, L. Comparison of chemical and physical indices of thermal stability of biochars from different biomass by analytical pyrolysis and thermogravimetry. J. Anal. Appl. Pyrolysis 2016, 122, 160-168. [CrossRef]

81. Das, O.; Bhattacharyya, D.; Sarmah, A.K. Sustainable eco-composites obtained from waste derived biochar: A consideration in performance properties, production costs, and environmental impact. J. Clean. Prod. 2016, 129, 159-168. [CrossRef]

82. Sgriccia, N.; Hawley, M. Thermal, morphological, and electrical characterization of microwave processed natural fiber composites. Compos. Sci. Technol. 2007, 67, 1986-1991. [CrossRef]

83. Das, O.; Kim, N.K.; Kalamkarov, A.L.; Sarmah, A.K.; Bhattacharyya, D. Biochar to the rescue: Balancing the fire performance and mechanical properties of polypropylene composites. Polym. Degrad. Stab. 2017, 144, 485-496. [CrossRef]

84. Chen, C.; Yan, X.; Xu, Y.; Yoza, B.A.; Wang, X.; Kou, Y.; Ye, H.; Wang, Q.; Li, Q.X. Activated petroleum waste sludge biochar for efficient catalytic ozonation of refinery wastewater. Sci. Total Environ. 2019, 651, 2631-2640. [CrossRef]

85. Pan, Y.; Gao, X.; Lei, J.; Li, Z.; Shen, K. Effect of different morphologies on the creep behavior of high-density polyethylene. RSC Adv. 2016, 6, 3470-3479. [CrossRef]

86. Qian, S.; Tao, Y.; Ruan, Y.; Lopez, C.A.F.; Xu, L. Ultrafine bamboo-char as a new reinforcement in poly (lactic acid)/bamboo particle biocomposites: The effects on mechanical, thermal, and morphological properties. J. Mater. Res. 2018, 33, 3870-3879. [CrossRef]

87. Qian, S.; Sheng, K.; Yao, W.; Yu, H. Poly (lactic acid) biocomposites reinforced with ultrafine bamboo-char: Morphology, mechanical, thermal, and water absorption properties. J. Appl. Polym. Sci. 2016, 133. [CrossRef]

88. Arrigo, R.; Bartoli, M.; Malucelli, G. Poly (lactic acid)-biochar biocomposites: Effect of processing and filler content on rheological, thermal, and mechanical properties. Polymers 2020, 12, 892. [CrossRef]

89. Nan, N.; DeVallance, D.B.; Xie, X.; Wang, J. The effect of bio-carbon addition on the electrical, mechanical, and thermal properties of polyvinyl alcohol/biochar composites. J. Compos. Mater. 2016, 50, 1161-1168. [CrossRef]

90. Noori, A.; Bartoli, M.; Frache, A.; Piatti, E.; Giorcelli, M.; Tagliaferro, A. Development of pressure-responsive polypropylene and biochar-based materials. Micromachines 2020, 11, 339. [CrossRef] 
91. Xu, J.; Liu, J.; Ling, P.; Zhang, X.; Xu, K.; He, L.; Wang, Y.; Su, S.; Hu, S.; Xiang, J. Raman spectroscopy of biochar from the pyrolysis of three typical Chinese biomasses: A novel method for rapidly evaluating the biochar property. Energy 2020, 202, 117644. [CrossRef]

92. Nan, N.; DeVallance, D.B. Development of poly (vinyl alcohol)/wood-derived biochar composites for use in pressure sensor applications. J. Mater. Sci. 2017, 52, 8247-8257. [CrossRef]

93. Savi, P.; Yasir, M.; Bartoli, M.; Giorcelli, M.; Longo, M. Electrical and microwave characterization of thermal annealed sewage sludge derived biochar composites. Appl. Sci. 2020, 10, 1334. [CrossRef]

94. Naeem, S.; Baheti, V.; Tunakova, V.; Militky, J.; Karthik, D.; Tomkova, B. Development of porous and electrically conductive activated carbon web for effective EMI shielding applications. Carbon 2017, 111, 439-447. [CrossRef]

95. Chen, B.; Zhou, D.; Zhu, L. Transitional adsorption and partition of nonpolar and polar aromatic contaminants by biochars of pine needles with different pyrolytic temperatures. Environ. Sci. Technol. 2008, 42, 5137-5143. [CrossRef]

96. Novák, I.; Krupa, I.; Chodák, I. Analysis of correlation between percolation concentration and elongation at break in filled electroconductive epoxy-based adhesives. Eur. Polym. J. 2003, 39, 585-592. [CrossRef]

97. Ahmetli, G.; Kocaman, S.; Ozaytekin, I.; Bozkurt, P. Epoxy composites based on inexpensive char filler obtained from plastic waste and natural resources. Polym. Compos. 2013, 34, 500-509. [CrossRef]

98. Özaytekin, İ.; Kar, Y. Synthesis and properties of composites of oligoazomethine with char. J. Appl. Polym. Sci. 2012, 123, 815-823. [CrossRef]

(C) 2020 by the authors. Licensee MDPI, Basel, Switzerland. This article is an open access article distributed under the terms and conditions of the Creative Commons Attribution (CC BY) license (http://creativecommons.org/licenses/by/4.0/). 